\title{
Evolution of Ryegrass Seed Banks Depending on Soil Tillage AND CROPS ${ }^{1}$
}

\author{
Evolução do Banco de Sementes de Azevém em Função do Manejo do Solo e de Culturas
}

GALVAN, J.2, RIZZARDI, M.A.², PERUZZO, S.T. ${ }^{2}$, and OVEJERO, R.F. ${ }^{3}$

\begin{abstract}
The seed bank is characterized by the amount of seeds and other viable reproductive structures in the soil and it is changed by the input and output of seeds, being classified by its permanence in the soil as transient or permanent. The tillage and crops used decisively influence this dynamic and more disturbed areas tend to have richer seed banks. The purpose of this study was to test different soil tillage and crop systems, aiming to reduce or eliminate the ryegrass in the area. The experiment was conducted from 2010 to 2012. In the first year, the effect of chemical tillage was assessed, compared to the area without tillage. From the second year on, in the area that received chemical tillage, the second experiment was installed, where it was assessed the effect of soil tillage and crop rotation in the ryegrass seed yield. The soil tillage treatment was chisel plow and non-chisel plow. The crop rotation was: fallow/ soybean; wheat/soybean; black oat/maize. The samples of soil were taken three times a year and split in 0-5, 5-10, 10-15 and 15-20 cm. After sampling, the seeds were separated from the soil and sterilized. Afterwards, germination and tetrazolium test were conducted. In the same plots used for soil sampling, the emergence flow of ryegrass was assessed in the winter 2011 and 2012. In the first year it was observed that chemical tillage had considerably reduced the amount of ryegrass in the soil. The crop rotations used were more effective than soil tillage in reducing the seed banks in the soil. The rotation oat/maize and wheat/soybean, in only two years, practically zeroed the ryegrass seed banks in the area.
\end{abstract}

Keywords: seed dormancy, chiseling, seeds viability, weeds.

RESUMO - O banco de sementes é composto por sementes e estruturas de reprodução viáveis, sendo alterado pela entrada e saida de sementes na área. Assim, o manejo das culturas utilizadas na área influencia na dinâmica do banco de sementes. Objetivou-se neste estudo testar manejos de solo e de culturas como forma de reduzir a presença de azevém. No primeiro ano, avaliou-se o efeito do manejo químico, em relação à área mantida sem manejo. A partir do segundo ano, na área manejada quimicamente, instalou-se um experimento, em que se avaliaram os efeitos do manejo de solo e de culturas na presença de propágulos e plântulas de azevém. O manejo de solo consistiu em escarificação e não escarificação. As sucessões de culturas foram: pousio/soja, trigo/soja, aveia-preta/soja e aveia-preta/milho. Foram realizadas coletas de solo nas profundidades de 0-5, 5-10, 10-15 e 15$20 \mathrm{~cm}$ em três épocas; as sementes de azevém coletadas foram submetidas ao teste de germinação em câmara de crescimento, com posterior teste de tetrazólio. Foi avaliado o fluxo de emergência de azevém nos periodos de inverno em 2011 e 2012. No primeiro ano, observou-se redução na quantidade de sementes de azevém no solo manejado quimicamente. As sucessões de culturas utilizadas mostraram-se mais efetivas na redução do banco de sementes. Observou-se que sucessões de aveiapreta/milho e trigo/soja, em dois anos, reduziram significativamente o banco de sementes na área.

Palavras-chave: dormência, escarificação, viabilidade de sementes, plantas daninhas.

Recebido para publicação em 18.9.2014 e aprovado em 3.3.2015.

Universidade de Passo Fundo, Passo Fundo-RS, Brasil, <rizzardi@upf.br>; ${ }^{3}$ Monsanto do Brasil, Piracicaba-SP, Brasil.

Planta Daninha, Viçosa-MG, v. 33, n. 2, p. 183-191, 2015 


\section{INTRODUCTION}

A seed bank is characterized by the amount of viable seeds and other propagation structures in the soil or in plant debris, and plays a crucial role in the replacement of eliminated plants, either by natural causes or not (Carmona, 1992).

The availability of seeds in the soil is characterized by its input, staying and output. According to Radosevich et al. (2007), input occurs by seed yield and dispersal, and the output is a result of germination, senescence, death and predation. Seed dormancy contributes to germination over time, which guarantees the potential of the seed bank regeneration even in adverse environmental conditions, and that can ensure the survival rate even when the vegetation is completely eliminated (Carmona, 1992).

The size of the seed bank of weeds is comparatively higher in agricultural areas than in non-agricultural areas of low environmental disturbance (Monquero \& Christofoletti, 2005). Fenner (1985) states that the largest seed banks from the point of view of number of seeds per area are associated with agricultural areas, and the smallest are associated with prairies, grasslands, wetlands and reserve forests.

Changes in the seed bank result, at certain times, in the required adoption of different tillages over the years, due to variable species and intensity present, which cause economic damage to crops (Voll et al., 2001). Any event that interferes with the number of seeds produced and added to the bank directly affects the density, the arrangement and the proportion of weeds infesting an area of future crops (Balbinot Jr. et al., 2002).

Studies on size, composition and determinants of formation of weed seed banks are of great economic and scientific interest, and critical to the development and application of agronomic techniques to control undesirable species, and provide the anticipation of agronomic tillage practices (Vismara et al., 2007).

The main limitation of the study of the weed seed bank is the inconsistency of the data obtained from the soil samples used to predict potential populations of these plants (Cardina \& Sparrow, 1996). Still, according to Forcella (1993), the tillage of the seed bank is a procedure to compose an integrated control program of the weeds.

The assessment of the seed bank is an important tool to verify the control efficiency of weeds over time (Marchezan et al., 2001). In the case of ryegrass, understanding its dynamics will assist in adopting long-term strategies to minimize the damage caused by this species in the different winter crops in southern Brazil. This damage decreases the wheat yield around $18-56 \%$, according to the population of ryegrass and wheat cultivar (Fleck, 1980).

This study aimed to test different tillage of soil and crops in order to assess the dynamics of a ryegrass seed bank and to reduce or eliminate this weed in the area.

\section{MATERIALS AND METHODS}

The experiment was conducted in the Brazilian city of Passo Fundo, RS, during the years 2010, 2011 and 2012. The soil is classified as humic Distrophic Red Oxisol. The climate, according to Köppen classification, is humid subtropical (Cfa).

The experiment was conducted in a winter fallow area, predominantly with ryegrass. In the first year of the experiment (2010/11), the area was divided into two, one being kept without chemical tillage and the other with chemical tillage. Chemical control has with glyphosate (750 g a.e. $\mathrm{ha}^{-1}$ ) and clethodim (120 g a.i. ha ${ }^{-1}$ ) 30 days before, and with paraquat + diuron $\left(400+200 \mathrm{~g}\right.$ a.i. $\left.\mathrm{ha}^{-1}\right)$ one day before sowing soybeans. On first application, the ryegrass was among the stages of blooming and soft dough.

The experimental design used in the first year was randomized blocks, in split plots. The assessment times (April, October and December) were considered as main plots, and chemical tillage as subplots. In the second and third years, the design was a randomized block design, in split plots. The assessment times (April, October and December) were the main plots; soil tillage (with and without chisel plow), the subplots; and the crop rotation (fallow/ 
soybean, wheat/soybean, black oat/soybean and black oat/maize), the sub-subplots.

After soybean harvest in mid-April 2011, in the area with chemical tillage in the first year, glyphosate (750 g a.e. ha ${ }^{-1}$ ) and clethodim (120 g a.i. ha-1) were used. Approximately ten days later, chisel plow was held.

Crops planted in winter, wheat and black oat, were sown in June for the years 2011 and 2012, and the wheat harvest took place in November. For the summer crops, maize was sown in September, and soybeans in November.

Before deploying the winter crops, the total area of the experiment received chemical tillage with glyphosate (720 g a.e. ha- $\mathrm{h}^{-1}$ ) and clethodim (120 g a.i. ha-1). In the area where wheat was cultivated, unlike in the other winter crops, iodosulfuron was applied in $5 \mathrm{~g}$ a.i. ha ${ }^{-1}$ dose, which has effect on ryegrass. In the areas of black oats and fallow, 2,4-D $(2,4$-Dichlorophenoxyacetic acid) at a dose of $670 \mathrm{~g}$ a.e. ha ${ }^{-1}$ was applied.

As for the summer crops, the area received chemical tillage with glyphosate $(1,080$ g a.e. ha-1) and clethodim (120 g a.e. ha-1) and sequentially with paraquat + diuron $\left(400+200 \mathrm{~g}\right.$ a.i. $\left.\mathrm{ha}^{-1}\right)$. In the area with soybean crops, herbicide chlorimuron was also used in preemergence of the crop at a dose of $20 \mathrm{~g}$ a.i. ha $\mathrm{h}^{-1}$ and in postemergence glyphosate was applied at $720 \mathrm{~g}$ a.e. ha ${ }^{-1}$. In postemergence maize, atrazine $\left(2,000 \mathrm{~g}^{\mathrm{a} . \mathrm{i}} . \mathrm{ha}^{-1}\right)$ and nicosulfuron (24 g a.i. ha ${ }^{-1}$ ) were used.

Soil samplings were obtained with stainless steel cylinders with diameter and height of $5 \mathrm{~cm}$ in the depths of $0-5,5-10,10-15$ and 15$20 \mathrm{~cm}$ in the usable area of the subplots. Samplings were obtained in April, September/ October and December 2010, 2011 and 2012.

After sampling, the ryegrass seeds were separated from the soil by washing under running water with screens of $2 \mathrm{~mm}$ and $425 \mu \mathrm{m}$. Then the material was dried in the shade with a paper towel in a ventilated environment, and the seeds were manually separated from the soil granules. After this procedure, the seeds were counted and placed for five minutes in $70 \%$ alcohol and for 20 minutes in $2 \%$ sodium hypochlorite for disinfection. Later, they were triply washed in running water.

After sterilization, the seeds were placed in germination boxes containing moistened germination paper with a water volume 2.5 times the mass of the paper. The germination boxes were placed in a BOD (Biochemical Oxygen Demand) type chamber of germination/growth, at a temperature of $20{ }^{\circ} \mathrm{C}$, light/dark photoperiod of 12 hours and light incidence of approximately 10.9 Klux. At 7 and 14 days after sowing, germination was assessed, being considered germinated the seed that showed visible extrusion of the radicle or coleoptile.

The seeds that did not germinate nor deteriorated were subjected to the tetrazolium test at a concentration of $0.5 \%$ for six hours at $30{ }^{\circ} \mathrm{C}$ temperature to assess the feasibility (Brasil, 2009).

Based on the data obtained by counting the whole seeds (seeds with whole embryo and at least part of the endosperm) and then in the germination and viability tests the amount of seeds per area was estimated. Having the amount of ryegrass seeds found whole by area, as well as the percentage of those which were alive (germinated in chambers, adding the feasible ones to the tetrazolium test), the percentage distribution of living seeds per square meter in the soil profile for each sampling carried out was calculated.

Also, with the results for the number of whole seeds sampled from different crops, the change in the seed bank over time was calculated from a formula modified by Marchezan et al. (2001):

Changing the seed bank $(\%)=\mid 100-$ ((NSref $x$ 100)/ NSant)|, where: NSref reference number to compare sampled ryegrass seeds and NSant - number of ryegrass seeds earlier sampled to which the comparison was made.

For the calculations of evolution of the seed bank, only the layer of $0-5 \mathrm{~cm}$ of soil was considered, for in a depth greater than $5 \mathrm{~cm}$ the percentage of seeds was low. Also, to compare the seed bank before and after chisel plow, the area where they underwent chemical tillage in 2010 was used as a reference. 
The ryegrass emergence assessments were carried out in 2011 and 2012. In 2011 two assessments were carried out, in the months of August and September. In 2012, there were 11 counts in the period between April 26 and October 5.

In each sub-subplot there were three counts, always in the same spot from which the local average was calculated. In plants count a PVC (poly(vinyl chloride)) frame was used, with the sides measuring $0.5 \mathrm{~m}$, corresponding to a sampling area of $0.25 \mathrm{~m}^{2}$.

The results obtained in the experiments were initially transformed into square root; then they were subjected to analysis of variance and the means were compared by Tukey test at $5 \%$ probability.

\section{RESULTS AND DISCUSSION}

Although soil samples were taken in four different depths, emphasis will be given only to data related to a depth of $0-5 \mathrm{~cm}$, since, in the others, few seeds were found and they were not feasible.

In the first sampling, held in October 2010, there were 255 whole seeds per $\mathrm{m}^{2}$ at a depth of $5-10 \mathrm{~cm}, 229$ in $10-15 \mathrm{~cm}$ and 255 in 15$20 \mathrm{~cm}$. However, only 12, 9 and 32 living seeds per $\mathrm{m}^{2}$, respectively. From December 2010, seeds were not found in the depths of 5-10 and 15-20 cm, and for 10-15 cm from April 2011. These data are in agreement with the findings of Carmona (1992), for whom few weed species emerge at depths greater than $5 \mathrm{~cm}$, except for those that have large seeds.

In the first sampling in October 2010, the number of ryegrass seeds sampled did not differ statistically among the chemical tillages, since this phase had not yet had the effect of the herbicide, which was soon applied (Table 1).

On the other hand, in the following assessments in December 2010 and April 2011, chemical tillage negatively influenced the yield and supply of the seed bank. In December 2010, in the area without herbicide application, the seed bank showed up to about 11 times higher than the area with chemical tillage. In the April 2011 assessment, the superiority was only four times (Table 1). This difference in the amount of seeds found in different periods can be explained by the fact that most of the seeds are derived from the natural dehiscence and remain in the surface of the soil, prone to environmental action, with loss of their viability.

In addition to the differences between the two chemical tillages, the sampling time also affected the amount of seeds found in the area without herbicide, with the largest quantities in the December sampling (Table 1). In the area where there was chemical tillage, the amount of seeds has not changed between the months of assessment, which is indicative of the small increase of seeds between October 2010 and April 2011, to the point of not being statistically significant.

Table 1 - Number of sampled ryegrass seeds, percentage of living seeds (germinated + tetrazolium) and ryegrass seed percentage, germinated in germination chamber and viable in tetrazolium test at a depth of $0-5 \mathrm{~cm}$, depending on the time of sampling and chemical tillage in the first year of the experiment - 2010/2011

\begin{tabular}{|c|c|c|c|c|c|c|c|c|}
\hline \multirow[b]{2}{*}{ Soil sampling season } & \multicolumn{2}{|c|}{ Sampled seeds $\mathrm{m}^{-2}$} & \multicolumn{2}{|c|}{ Living seeds (\%) } & \multicolumn{2}{|c|}{$\begin{array}{c}\text { Seeds germinated in a } \\
\text { chamber (\%) }\end{array}$} & \multicolumn{2}{|c|}{$\begin{array}{l}\text { Viable seeds in the } \\
\text { tetrazolium test (\%) }\end{array}$} \\
\hline & $\begin{array}{c}\text { With } \\
\text { chemical } \\
\text { tillage }\end{array}$ & $\begin{array}{c}\text { Without } \\
\text { chemical } \\
\text { tillage }\end{array}$ & $\begin{array}{c}\text { With } \\
\text { chemical } \\
\text { tillage }\end{array}$ & $\begin{array}{c}\text { Without } \\
\text { chemical } \\
\text { tillage }\end{array}$ & $\begin{array}{c}\text { With } \\
\text { chemical } \\
\text { tillage }\end{array}$ & $\begin{array}{c}\text { Without } \\
\text { chemical } \\
\text { tillage }\end{array}$ & $\begin{array}{c}\text { With } \\
\text { chemical } \\
\text { tillage }\end{array}$ & $\begin{array}{c}\text { Without } \\
\text { chemical } \\
\text { tillage }\end{array}$ \\
\hline Oct/10 & A 2,164 a & A $2,953 \mathrm{c}$ & A 38.3 a & A 24.4 b & A 25.8 a & A $12.4 \mathrm{~b}$ & $12.5^{\mathrm{ns}}$ & $12.1^{\mathrm{ns}}$ \\
\hline Dec/10 & B 2,953 a & A 32,111 a & B 49.7 a & A 78.0 a & B 29.3 a & A 56.2 a & 20.3 & 21.8 \\
\hline Apr/11 & B 3,522 a & A $14,430 \mathrm{~b}$ & A 36.7 a & A $51.1 \mathrm{a}$ & B $11.8 \mathrm{a}$ & A $31.2 \mathrm{ab}$ & 24.9 & 19.9 \\
\hline CV season $(\%)$ & \multicolumn{2}{|c|}{19.1} & \multicolumn{2}{|c|}{16.9} & \multicolumn{2}{|c|}{29.7} & \multicolumn{2}{|c|}{15.2} \\
\hline CV chemical tillage (\%) & \multicolumn{2}{|c|}{35.8} & \multicolumn{2}{|c|}{13.2} & \multicolumn{2}{|c|}{20.1} & \multicolumn{2}{|c|}{14.5} \\
\hline
\end{tabular}

Means preceded by the same capital letter in the row and followed by the same lowercase letter in the column do not differ by Tukey test $(\mathrm{P}<0.05)$. ${ }^{\text {ns }}$ Non-significant means by Tukey test $(\mathrm{P}<0.05)$. 
The results of the calculations of evolution of the seed bank due to the tillage used the first year showed increments of seeds in both treatments between October and December 2010; however, the control plot reached almost $1,000 \%$ increase, while in the area with chemical tillage this increase was less than $37 \%$.

As for the percentage of living seeds, it was possible to see a reduced incorporation of new seeds in the area dried out in advance, with no difference between the months of sampling (Table 1). On the other hand, in the nondesiccated area the increase of the percentage of living seeds was high, since in this area the plants had finished their cycle and replenished the system yielding viable seeds.

When assessing the percentage of seeds germinated in a germination chamber, there were no significant differences among the assessment periods; however, in the control area the percentage of seeds germinated in December was higher than 4.5 times compared to October, and 1.8 times compared to April (Table 1). Regarding the percentage of viable seeds subjected to the tetrazolium test, chemical tillage and the sampling time showed similar behavior (Table 1).

The amount of seeds sampled in the soil, in the fallow/soybean rotation, was higher than the others, except for the first three samples, when it was not different from the black oat/soybean rotation (Table 2). The amount of seeds per area, regardless of the time of sampling, remained similar in the wheat/soybean and black oat/maize rotations.

The absence of differences between fallow/ soybean and black oat/soybean in the first year of the experiment was due to the absence of a herbicide selective to black oat and that had control only over ryegrass. In the second year, with the reduction of seeds in the previous year, added to the fact of the use of a cultivar with a higher biomass yield, which practically prevented the development of ryegrass, the reduction of seeds in the soil was sharp, matching the treatments wheat/ soybean and black oat/maize.

At the end of 2012, the amount of seeds found in the fallow/soybean rotation was more than 100 times higher than that found in
Table 2 - Ryegrass seed amount sampled at a depth of 0-5 cm, depending on the time of sampling and crop rotation, in the average of soil tillage - 2011/2012

\begin{tabular}{|l|c|c|c|c|}
\hline \multirow{2}{*}{$\begin{array}{c}\text { Soil sampling } \\
\text { season }\end{array}$} & \multicolumn{4}{|c|}{ Sampled seeds m ${ }^{-2}$} \\
\cline { 2 - 5 } & ${\mathrm{F} / \mathrm{S}^{2} /}^{-1}$ & W/S & BO/S & BO/M \\
\hline October/11 & A 369 d ${ }^{1 /}$ & B 90 a & AB 204 b & B 76 a \\
\hline December/11 & A 2,143 b & B 255 a & A 1,719 a & B 170 a \\
\hline April/12 & A 1.061 c & B 127 a & A 955 a & B 191 a \\
\hline October/12 & A 721 cd & C 42 a & B 233 b & C 42 a \\
\hline December/12 & A 4,456 a & B 38 a & B 38 b & B 13 a \\
\hline CV season (\%) & \multicolumn{4}{|c}{64.2} \\
\hline CV crops (\%) & \multicolumn{4}{|c}{44.4} \\
\hline
\end{tabular}

${ }_{1}^{1}$ Means preceded by the same capital letter in the row and followed by the same lowercase letter in the column do not differ by Tukey test $(\mathrm{P}<0.05)$ ? $/ \quad$ Crop rotation: $\mathrm{F} / \mathrm{S}=$ fallow/soybean; $\mathrm{W} / \mathrm{S}=$ wheat $/$ soybean; $\mathrm{BO} / \mathrm{S}=$ black oat $/$ soybean; $\mathrm{BO} / \mathrm{M}=$ black oat/maize.

other rotations, and between October and December 2012 the amount of seeds in the black oat/soybean treatment abruptly reduced (Table 2).

As a result of the evolution of the seed bank in the second and third years of the experiment, the amount of seeds increased for all crops rotation only between October and December 2011. As early as 2012, in the same period, only the area kept in winter fallow increased the seed bank (Table 2). For the period between December 2011 and 2012, the fallow/soybean rotation increased the seeds by $108 \%$, but the other rotations reduced by more than $85 \%$ (Table 2).

When looking at the seed bank behavior during the two years between December 2010 and December 2012, in the area with chemical tillage in 2010, the fallow/soybean rotation increased by approximately $51 \%$ the seeds in the soil. On the other hand, if the control area is observed in 2010, the decrease was more than $86 \%$ (Table 2). This reduction was due solely to the application of herbicides held in 2010 in the fallow area, since in this one ryegrass was no longer controlled with herbicides.

Thus, both when comparing the area with chemical tillage and the control area of 2010 to the other crop rotations in 2012, it is observed that the reduction in the seed bank, in all situations, exceeded 98\% (Table 2). These data reinforce the importance of crop rotation to reduce ryegrass seed bank. 
In assessing seed germination in a chamber, it is possible to see that, contrary to the situation on the experiment in the first year, between 2010 and 2011, the highest values were obtained in April in all crop rotations, which corresponded to the better time for seed germination in the field (Table 3). In the other sampling times, when germination occurred, it was a small percentage.

The percentage of viable seeds in the tetrazolium test did not differ among the assessment periods; as for the assessment of living seeds, it was possible to observe that the period encompassing April showed 59.3\% of living seeds (Table 4), but with significant differences among the crops rotations. It is observed that the treatment fallow/soybean is higher than the one for black oat/soybean, and this, in turn, was higher than the one for wheat/soybean and black oat/maize (Table 4). In a way, this may reflect the input of seeds into the system, as the fallow/soybean rotation was replenished every year.

These results are even more evident when they refine the assessment of the amount of living seeds in each crop rotation. Fallow/soybean, which allowed the input of seeds in large quantities every year, showed more than $70 \%$ of their living seeds, whereas wheat/soybean and black oat/maize showed approximately $30 \%$ living seeds, since these rotations substantially reduced or even prevented the input of new seeds in the soil.

In relation to the vertical distribution of ryegrass living seeds in the soil, it was observed that in all crop rotations, regardless of soil tillage, all the seeds were present in

Table 3 - Ryegrass seeds percentage germinated in a germination chamber, depending on the time of sampling and crop rotation, and percentage of viable ryegrass in tetrazolium test and alive (germinated + tetrazolium) depending on sampling time in the average of soil tillage - 2011/2012

\begin{tabular}{|c|c|c|c|c|c|c|}
\hline \multirow{2}{*}{ Soil sampling season } & \multicolumn{4}{|c|}{ Seeds germinated in a chamber (\%) } & \multirow{2}{*}{$\begin{array}{l}\text { Viable seeds in } \\
\text { tetrazolium (\%) }\end{array}$} & \multirow{2}{*}{ Living seeds (\%) } \\
\hline & $\mathrm{F} / \mathrm{S}^{\underline{2} /}$ & W/S & $\mathrm{BO} / \mathrm{S}$ & $\mathrm{BO} / \mathrm{M}$ & & \\
\hline Oct/11 & A $0.0 c^{\underline{1}}$ & A $0.0 \mathrm{a}$ & A $0.0 \mathrm{~b}$ & A $0.0 \mathrm{~b}$ & $52.2^{\text {ns }}$ & 52.2 abc* $^{*}$ \\
\hline Dec/11 & A $0.0 \mathrm{c}$ & A $0.0 \mathrm{a}$ & A $0.0 \mathrm{~b}$ & A $0.0 \mathrm{~b}$ & 49.4 & $49.4 \mathrm{ab}$ \\
\hline Apr/12 & A 48.8 a & B $10.4 \mathrm{a}$ & A 38.0 a & B $25.0 \mathrm{a}$ & 28.7 & $59.3 \mathrm{a}$ \\
\hline Oct/12 & A 4.2 c & A $0.0 \mathrm{a}$ & A $0.0 \mathrm{~b}$ & A $0.0 \mathrm{~b}$ & 26.8 & $27.9 \mathrm{c}$ \\
\hline Dec/12 & A $10.0 \mathrm{~b}$ & B $0.0 \mathrm{a}$ & B $12.5 \mathrm{~b}$ & B $0.0 \mathrm{~b}$ & 28.6 & $34.3 \mathrm{bc}$ \\
\hline CV season (\%) & \multicolumn{4}{|c|}{170.9} & 70.6 & 63.9 \\
\hline CV crops (\%) & \multicolumn{4}{|c|}{123.9} & - & - \\
\hline
\end{tabular}

${ }^{1 /}$ Means preceded by the same capital letter in the row and followed by the same lowercase letter in the column do not differ by Tukey test $(\mathrm{P}<0.05) .{ }^{2} /$ Crop rotation: $\mathrm{F} / \mathrm{S}=$ fallow/soybean; W/S = wheat/soybean; BO/S = black oat $/$ soybean; BO/M = black oat $/ \mathrm{maize} .{ }^{\text {ns }}$ Nonsignificant means by Tukey test $(\mathrm{P}<0.05) .{ }^{*}$ Means followed by the same letter in the column do not differ by Tukey test $(\mathrm{P}<0.05)$.

Table 4 - Percentage of viable ryegrass seeds in tetrazolium test and alive (germinated + tetrazolium), depending on the crop rotation and ryegrass plants emerged $\left(\mathrm{m}^{2}\right)$ for different crop rotations and sampling time - 2011

\begin{tabular}{|c|c|c|c|c|}
\hline \multirow{2}{*}{ Crop rotation } & \multirow{2}{*}{$\begin{array}{l}\text { Viable seeds in } \\
\text { tetrazolium (\%) }\end{array}$} & \multirow{2}{*}{ Living seeds (\%) } & \multicolumn{2}{|c|}{ Sampling season } \\
\hline & & & August & September \\
\hline Fallow/Soybean & $57.9 a^{1 /}$ & $70.4 \mathrm{a}$ & A $97.5 \mathrm{a}^{2 /}$ & A 90.6 a \\
\hline Wheat/Soybean & 26.2 c & $28.3 \mathrm{c}$ & A 88.2 a & C $10.1 \mathrm{~b}$ \\
\hline Oat/Soybean & $39.2 \mathrm{~b}$ & $49.3 \mathrm{~b}$ & A $93.4 \mathrm{a}$ & $\mathrm{AB} 60.5 \mathrm{~b}$ \\
\hline Oat/Maize & $25.4 \mathrm{c}$ & $30.4 \mathrm{c}$ & A 103.7 a & B $54.6 \mathrm{~b}$ \\
\hline CV (\%) & 70.6 & 63.9 & \multicolumn{2}{|c|}{17.2} \\
\hline CV crops (\%) & - & - & \multicolumn{2}{|c|}{18.4} \\
\hline
\end{tabular}

${ }^{1 /}$ Means followed by the same letter in the column do not differ by Tukey test $(\mathrm{P}<0.05) .{ }^{2}$ 'Means preceded by the same capital letter in the row and followed by the same lowercase letter in the column do not differ by Tukey test $(\mathrm{P}<0.05)$. 
the first soil layer. Direct sowing, or surface preparation, results in the concentration of weed seeds near the soil surface. Buhler et al. (1997) claim that the reduction or elimination of tillage influences the distribution of seeds in the soil. Cardina et al. (1991) found 70-78\% of the seeds distributed from 0 to $5 \mathrm{~cm}, 14$ to $20 \%$ at a depth of $5-10 \mathrm{~cm}$ and only 5 to $10 \%$ at a depth of 10-15 cm. Comparing the behaviors among species with respect to tillages, it is observed that the grasses had a lower survival period in tillage, compared to other soil movement tillages, while eudicotyledonous showed a higher survival period (Voll et al., 2001).

Soil tillage did not influence the emergence of ryegrass plants, be it alone or interacting with the other factors assessed. Thus, the effect provided by soil chisel plow, be it by decompression or superficial change, however small, of the straw coverage and, consequently, also of the seed bank present, had no effect on the ryegrass emergence.

While in the area in fallow the amount of ryegrass plants occurring has stabilized, in areas where there was black oat the amount of plants decreased in September compared with August. For the wheat area, the reduction was greater, since for the ryegrass crop weeds are important, and thus their tillage is done with the use of a herbicide selective to the crop.

In the plots where black oat was cultivated, reducing the amount of ryegrass plants was due exclusively to the relationship between the two species, as chemical tillage on the ryegrass was not done. The reason for this decrease could not be identified but possibly it was the competition for vital resources common to both species, since oat had larger sized and more aggressive plants than ryegrass.

The assessment of ryegrass emergence in 2012 , just as in 2011 , shows that soil tillage did not influence the emergence of ryegrass plants when assessed alone; however, it significantly interacted with rotation planting and time of sampling.

The interaction of the sample time with soil tillage showed that, regardless of the sampled time, soil tillage, in the average of crop rotation, had no effect on the number of emerged plants (Table 5).

With regard to the interaction of the crops rotation with assessment times, the effect of the tillage practices used for each crop in the field has been shown, as well as the relationship among these species (Table 5).

The black oat/maize rotation showed the lowest amount of ryegrass plants emerged per area, a fact that is mainly explained by the history of the area; tillage in the previous year (2011) was the same this year, with the area desiccation for maize sowing being held before the reproductive stage of the plants.

Also, reflecting the year 2011, the ryegrass plants that emerged after sowing maize have not completed their cycle either, because the postemergence herbicides for weed tillage in maize crop, such as atrazine and nicosulfuron, acted effectively also on ryegrass.

Thus, it can be said that the ryegrass plant emerged in the black oat/maize rotation in 2012 was derived from the seeds in the soil produced in previous years and which remained dormant. Obviously, the traffic of machinery, animals and people, as well as environmental effects such as wind or rain, can carry seeds and thus interfere with the dynamics of the seed bank. However, in the specific case of the experiment, if this occurred, it was small.

The opposite of black oat/maize rotation can be seen in fallow/soybean, since it presented, in all assessments, the largest number of plants per area, except between the first and fourth sampling times, when it was equal to black oat/soybean, but higher than the others (Table 5).

The reduction in the number of plants per area between the third and fifth assessments was due to the effect of intense frosts, which caused the death of some ryegrass plants, even though this kind is adapted to cold. Later, in the last three assessments, the number of plants has stabilized, as the availability of resources and space is finite. Moreover, as ryegrass has a staggered germination during its cycle, the plants that had first been established had a competitive advantage and greater use of available resources. 
Table 5 - Ryegrass plants emerged $\left(\mathrm{m}^{2}\right)$ depending on soil tillage, crop rotation and sampling time of the plants in soil tillage average $-2012$

\begin{tabular}{|c|c|c|c|c|c|c|}
\hline \multirow[b]{2}{*}{ Sampling season } & \multicolumn{2}{|c|}{ Soil tillage } & \multicolumn{4}{|c|}{ Crop rotation } \\
\hline & $\begin{array}{c}\text { Without chisel } \\
\text { plow }\end{array}$ & $\begin{array}{c}\text { With chisel } \\
\text { plow }\end{array}$ & $\begin{array}{l}\text { Fallow/ } \\
\text { Soybean }\end{array}$ & $\begin{array}{l}\text { Wheat/ } \\
\text { Soybean }\end{array}$ & Oat/Soybean & Oat/Maize \\
\hline April 26 & A 31.6 abc & A $22.1 \mathrm{ab}$ & A $56.0 \mathrm{~d}$ & B $3.0 \mathrm{ab}$ & A $47.3 \mathrm{abc}$ & B $1.0 \mathrm{a}$ \\
\hline May 4 & A $49.7 \mathrm{ab}$ & A $37.6 \mathrm{a}$ & A $78.5 \mathrm{~cd}$ & B $10.3 \mathrm{ab}$ & A 84.2 ab & B 1.5 a \\
\hline May 11 & A 62.6 a & A 42.7 a & A $97.5 \mathrm{~cd}$ & B 26.7 a & AB 85.3 a & C $1.0 \mathrm{a}$ \\
\hline May 18 & A 56.7 a & A 42.2 a & A $87.8 \mathrm{~cd}$ & B $15.3 \mathrm{ab}$ & A 93.3 a & B $1.3 \mathrm{a}$ \\
\hline June 4 & A 26.2 c & A $14.0 \mathrm{~b}$ & A $80.3 \mathrm{~cd}$ & B $0.0 \mathrm{~b}$ & B 0.0 e & B 0.0 a \\
\hline June 21 & A 31.1 bc & A $20.8 \mathrm{ab}$ & A $92.0 \mathrm{~cd}$ & B $2.8 \mathrm{ab}$ & B 8.0 de & B $1.0 \mathrm{a}$ \\
\hline July 20 & A $41.2 \mathrm{ab}$ & A 33.5 a & A 116.8 bc & $\mathrm{BC} 4.7 \mathrm{ab}$ & B $26.5 \mathrm{~cd}$ & C $1.3 \mathrm{a}$ \\
\hline August 23 & A $43.7 \mathrm{ab}$ & A 39.9 a & A 121.8 bc & C $3.2 \mathrm{ab}$ & B 39.7 bcd & C 2.5 a \\
\hline September 7 & A $59.4 \mathrm{ab}$ & A 63.9 a & A 229.2 a & $\mathrm{B} 1.0 \mathrm{~b}$ & B 14.0 cde & B 2.5 a \\
\hline September 21 & A $54.2 \mathrm{ab}$ & A 57.6 a & A $200.2 \mathrm{ab}$ & $\mathrm{C} 1.7 \mathrm{ab}$ & B $21.7 \mathrm{~cd}$ & $\mathrm{C} 0.0 \mathrm{a}$ \\
\hline October 5 & A $53.6 \mathrm{ab}$ & A 56.7 a & A $201.0 \mathrm{ab}$ & $\mathrm{C} 0.3 \mathrm{~b}$ & B $19.3 \mathrm{~cd}$ & C $0.0 \mathrm{a}$ \\
\hline CV season (\%) & \multicolumn{2}{|c|}{36.4} & \multicolumn{4}{|c|}{36.4} \\
\hline CVM soil (\%) & \multicolumn{2}{|c|}{50.4} & \multicolumn{4}{|c|}{-} \\
\hline CV S crops (\%) & \multicolumn{2}{|c|}{-} & \multicolumn{4}{|c|}{52.5} \\
\hline
\end{tabular}

Means preceded by the same capital letter in the row and followed by the same lowercase letter in the column do not differ by Tukey test $(\mathrm{P}<0.05)$.

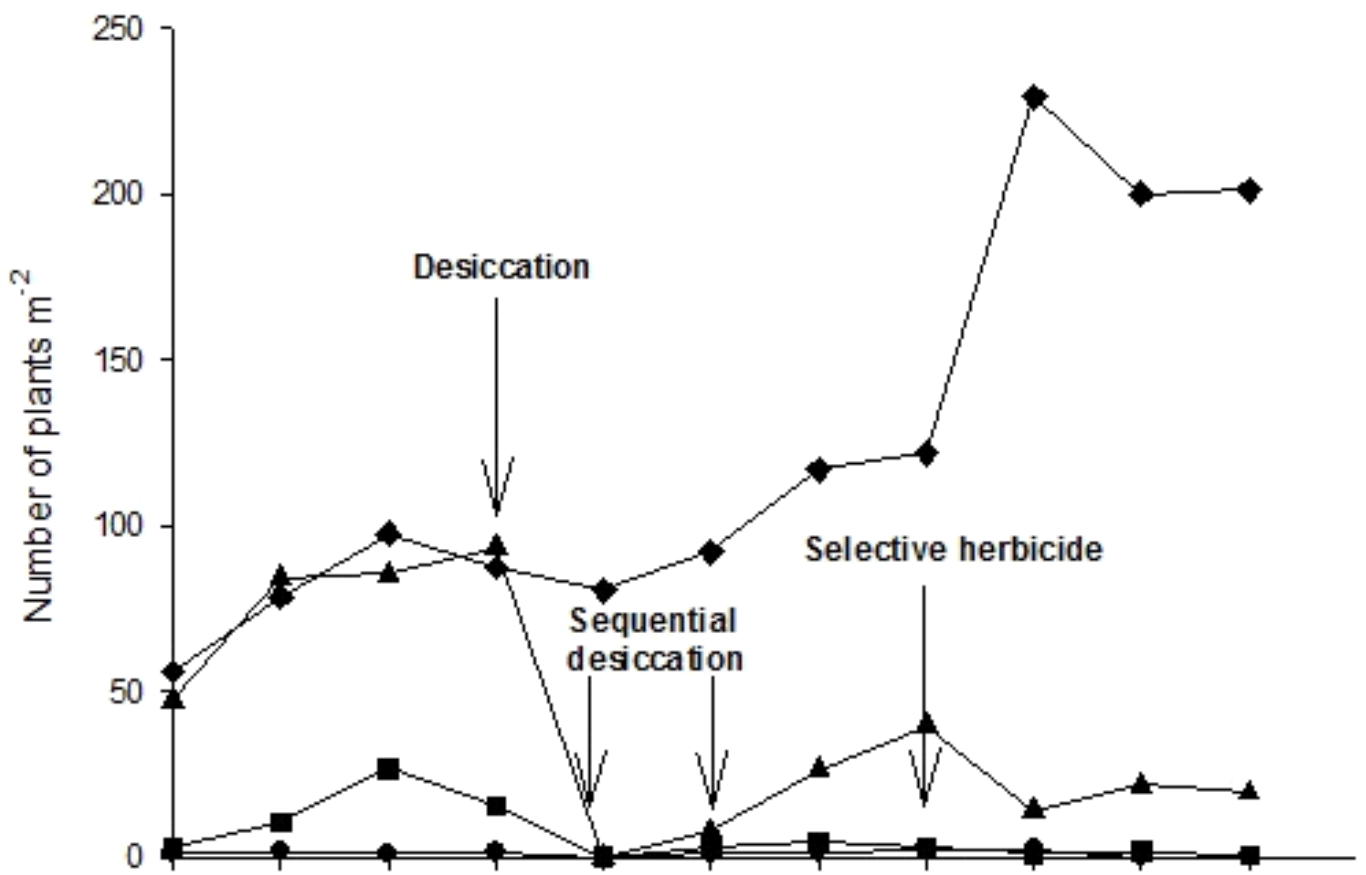

Apr 26 May 4 May 11 May 18 Jun 4 Jun 21 Jul20 Aug 23 Sep 7 Sep 21 Oct 5

Date of count

$(\neg)$ fallow/soybean $(-$ ) wheat/soybean; $(\neg)$ ) black oat/soybean; $(-\bullet)$ ) black oat/maize.

Figure 1 - Ryegrass emergence flow under different crop rotations in the average of the soil tillage in 2012 sampling. 
The black oat/soybean rotation had a high number of plants per area unit, which did not differ statistically from the fallow/soybean treatment until the fourth assessment; as for wheat/soybean the amount of emerged plants per area was similar to that of black oat/maize, exceeding this one only in the third assessment (Table 5).

The emergence of ryegrass in 2012 demonstrated the effects of crop rotations, with all their associated tillage in the population dynamics of weeds that occurred in this same area, which reinforces the fact that each crop has its associated weeds, with greater capacity to establish in the area (Figure 1).

Thus, the crop planning in the area is characterized as one of the pillars of the tillage system on straw and helps reduce the seed bank, especially because it avoids the predominance of certain weeds in the area, since each crop used has different resource requirements and admits different tillages.

\section{LITERATURE CITED}

BALBINOT Jr., A. A. et al. Predação de sementes de plantas daninhas em áreas cultivadas. Ci. Rural, v. 32, n. 4, p. 707-714, 2002.

BRASIL. Ministério da Agricultura, Pecuária e Abastecimento. Regras para análise de sementes. Brasília: 2009. 399 p.

BUHLER, D. D.; HARTZLER, R. G.; FORCELLA, F. Implications of weed seedbank dynamics to weed management. Weed Sci., v. 45, n. 3, p.329-336, 1997.

CARDINA, J.; REGNIER, E.; HARRISON, K. Long-term tillage effects on seed banks in three Ohio soils. Weed Sci., v. 39, p. 186-194, 1991.
CARDINA, J.; SPARROW, D. H. A comparison of methods to predict weed seedling populations from the soil seedbank. Weed Sci., v. 44, n. 1, p. 46-51, 1996.

CARMONA, R. Problemática e manejo de bancos de sementes de invasoras em solos agrícolas. Planta Daninha, v. 10, n. 1/2, p. 5-16, 1992.

FENNER, M. Seed ecology. New York: Chapman \& Hall, 1985. 325 p.

FLECK, N. G. Competição de azevém (Lolium multiflorum L.) com duas cultivares de trigo. Planta Daninha, v. 3, n. 2, p. 61-67, 1980.

FORCELLA, F. Seedling emergence model for velvetleaf. Agron. J., v. 85, n. 2, p. 929-933, 1993.

MARCHEZAN, E. et al. Eficiência da avaliação do banco de sementes na predição da infestação por arroz vermelho e rendimento de grãos do arroz irrigado após dois anos de rotação de cultura e pousio do solo. R. Bras. Agrosci., v. 7, n. 1, p. 15-17, 2001.

MONQUERO, P. A.; CHRISTOFFOLETI, P. J. Banco de sementes de plantas daninhas a herbicidas como fator de seleção. Bragantia, v. 64, n. 2, p. 203-209, 2005.

RADOSEVICH, S. R.; HOLT, J. S.; GHERSA, C. M. Ecology of weeds and invasive plants: relationship to agriculture and natural resource management. New Jersey: John Wiley \& Sons, 2007. 454 p.

VISMARA, L. S.; OLIVEIRA, V. A.; KARAM, D. Revisão de modelos matemáticos da dinâmica do banco de sementes de plantas daninhas em agrossistemas. Planta Daninha, v. 25, n. 1, p. 1-11, 2007.

VOLL, E. et al. Dinâmica do banco de sementes de plantas daninhas sob diferentes sistemas de manejo de solo. Planta Daninha, v. 19, n. 2, p. 171-178, 2001. 